Doi: HTTPS://DOI.ORG/10.23910/IJBSM/2017.8.4.1805a

\title{
Evaluate the Suitability of Bush Bean with the Application of Nitrogenous Fertilizer
}

\author{
Alok Kumar Paul ${ }^{*}$, Saima Sultana, Mst. Musharrat Zahan and Tarun Kumar Bala
}

Dept. of Soil Science, Sher-e-Bangla Agricultural University, Dhaka (12 07), Bangladesh

\section{Corresponding Author}

Alok Kumar Paul

e-mail: alokpaulsau@yahoo.com

\author{
Article History \\ Article ID: AR1805a \\ Received in $7^{\text {th }}$ March, 2017 \\ Received in revised form $19^{\text {th }}$ July, 2017 \\ Accepted in $2^{\text {nd }}$ August, 2017
}

\begin{abstract}
An experiment was conducted at Sher-e-Bangla Agricultural University farm, Dhaka during November, 2011 to March, 2012 to evaluate the suitability of BARI bush bean-1 with the application of nitrogenous fertilizer. The experiment was laid out following Randomized Complete Block Design (RCBD) with three replications. The source of the nitrogenous fertilizer was urea and organic manure cowdung. There are nine treatments i.e., $90 \mathrm{~kg} \mathrm{~N}$ supplied from urea; $80 \mathrm{~kg} \mathrm{~N}$ from urea+10 kg N supplemented by cowdung; $70 \mathrm{~kg} \mathrm{~N}$ from urea+20 kg N supplemented by cowdung; $60 \mathrm{~kg} \mathrm{~N}$ from urea $+30 \mathrm{~kg} \mathrm{~N}$ supplemented by cowdung; $50 \mathrm{~kg} \mathrm{~N}$ from urea $+40 \mathrm{~kg}$ N supplemented by cowdung; $40 \mathrm{~kg} \mathrm{~N}$ from urea+50 kg N supplemented by cowdung; $30 \mathrm{~kg} \mathrm{~N}$ from urea+60 kg N supplemented by cowdung; $90 \mathrm{~kg} N$ supplied from cowdung and control. BARI bush bean-1 variety was used as test crop. The result revealed that application of nitrogenous fertilizer from different sources found to be positive and significant on the growth and yield of bush bean. The highest plant height ( $43.67 \mathrm{~cm})$, maximum number of plants $\mathrm{m}^{-2}(27.33)$, maximum number of seeds pod $^{-1}(6.50)$, maximum number of branches plant ${ }^{-1}(7.66)$, maximum number of flowers plant ${ }^{-1}(27.67)$, highest pods plant ${ }^{-1}(25.0)$, longest pods length $(12.89 \mathrm{~cm})$ and the highest pod $\left(13.44 \mathrm{t} \mathrm{ha}^{-1}\right)$ yield was recorded from $50 \mathrm{~kg} \mathrm{~N}$ from urea+40 kg N supplemented by cowdung In all case, lowest result was obtained from control treatment with no fertilizer.
\end{abstract}

Keywords: Bush bean, cowdung, nitrogen, urea, yield

\section{Introduction}

Bush bean (Phaseolus vulgaris L.) is an important vegetables crop belonging to the family Leguminosae and sub-family Papiolionaceae, which was originated in the Central and South America (Swiader et al., 1992). It is also known as French bean, Kidney bean, Snap bean, Green bean, Raj bean, Navy bean, Pole bean, Wax bean and Bonchi in different countries of the World (Duke, 1983; Salukhe et al., 1987; Tindall, 1988). In our country it is known as 'Farashi Seem' (Rashid, 1993). Bush bean is mainly used as green vegetables and its young pods and mature seeds are used as cooked vegetables.

Bush bean is widely cultivated in the temperate and subtropical regions, and also in many parts of the tropics (Purseglove, 1987). It is more suitable as a winter crop in the north-eastern parts of India (AICPIP, 1987). According to FAO, bush bean occupied 27.08 mha of the World's cropped area and the production of dry pods was about $18.94 \mathrm{mt}$ with an average yield of $699 \mathrm{~kg} \mathrm{ha}^{-1}$ (FAO, 2000). In Bangladesh it is cultivated in Sylhet, Cox's Bazar, Chittagong Hill Tracts and some other parts of the country in a limited scale. Its edible pods supply protein, carbohydrate, fat, fibre, thiamin, riboflavin, $\mathrm{Ca}$ and Fe (Shanmugavelu, 1989) and the seed contains significant amount of thiamin, niacin, folic acid (Rashid, 1993). Recently cultivation of bush bean is gaining popularity in Bangladesh mainly because of its demand as a commodity for export.

The essential plant nutrient elements must be present in soil in optimum levels and in available forms for normal plant growth and development. Nitrogen is one of the most essential plant nutrient elements for crop production. Bush bean cultivation requires ample supply of nitrogen. It encourages vegetative growth and increases leaf area of plants, which helps in photosynthetic activity. It stimulates root growth and development of the plant. Furthermore, it helps in uptake of other nutrients from the soil. Unlike other leguminous crops bush bean does not nodulate with the native Rhizobia (Ali and Kushwaha, 1987). So, nitrogenous fertilizers application is essential for this crop. Fertilizer placement at 10-15 cm depth has promoted growth and development of root and shoot of bush bean (Chaib et al., 1984). Both excess and under doses of nitrogen hampered the yield. So for higher yield, judicious amount of nitrogen should be applied.

The application of different fertilizers and manures affect the physical and chemical properties and enhance the metabolic activities of soil. Organic matter is the key indicator of soil 
health but plants uptake majority of nutrients in an inorganic form. Therefore, the nutrients in organic matter need to undergo biological breakdown or mineralization in the soil before they are available to the plants. In addition to providing nutrients and habitat to organisms living in the soil, organic matter also binds soil particles into aggregates and improves the water holding capacity of soil. Incorporation of crop residue and cowdung increases the organic carbon and other nutrient content of soils (Saha et al., 2007) and increases crop yields (Bhatnagar et al., 1983). Organic manures supplies most of the nitrogen, sulphur and half phosphorus needed by unfertilized crops. The value of organic amendments in crop production is centered on the ability of animals and plants to provide nutrients and to improve the chemical, physical and biological properties of soils (IFIA, 1992). The regular addition of organic manure to soil is very important in the developing world of the tropics, where most traditional farming systems are not sustainable (Sangakkara, 1993). Organic manure improves soil tilth, infiltration rate and soil water holding capacity; contributes nutrient to the crop and it is an important source of raw or partially decomposed organic matter (Bill, 2001).

Several types of complexities may arise due to the unbalanced concentrations of different nutrients and as a consequence nutrient deficiencies. Use of organic matter with common chemical source of plant nutrients is one of the easy and simple ways to increase the total and quality yield of bush bean. So it is important to develop an integrated organicinorganic fertilization programme for achieving higher crop yield without affecting soil health. Considering the above condition the present experiment has been undertaken to evaluate the suitability of BARI bush bean-1 with the application of nitrogenous fertilizer from different organic and inorganic sources.

\section{Materials and Methods}

The experiment was carried out at Sher-e-Bangla Agricultural University farm, Sher-e-Bangla Nagar, Dhaka, Bangladesh during the period of mid November, 2011 to mid March, 2012. The location of the experimental site is $23^{\circ} 74^{\prime} \mathrm{N}$ latitude and $90^{\circ} 35^{\prime} \mathrm{E}$ longitude and an elevation of $8.2 \mathrm{~m} \mathrm{MSL}$ (Anonymous, 1989). The soil belongs to the Tejgaon series under the Agroecological Zone, Madhupur Tract (AEZ-28) and the General Soil Type is Deep Red Brown Terrace Soils. A composite soil sample at $0-15 \mathrm{~cm}$ depth was collected from the experimental field and analyzed for soil characteristics before the initiation of the experiment. The soil is Silty Clay Loam in texture having $\mathrm{pH} 6$ and contains organic matter $0.84 \%$, total nitrogen $0.067 \%$, available phosphorus 22.0 ppm and exchangeable potassium 0.12 meq $100 \mathrm{~g}^{-1}$ soils. BARI bush bean-1 variety was used for the study, this variety was developed by BARI and exposed for cultivation in the year of 1996 (BARI, 2006). The experiment was laid out in Randomized Complete Block Design (RCBD) with three replications and nine treatments. The field was divided into three blocks and each block was divided into 9 plots. Size of the plot was $2.5 \times 2.5 \mathrm{~m}^{2}$. The distance between two blocks and two plots were $50 \mathrm{~cm}$. Treatments of the experiment were:

$\mathrm{T}_{1}: 90 \mathrm{~kg} \mathrm{~N}$ supplied from urea; $\mathrm{T}_{2}: 80 \mathrm{~kg} \mathrm{~N}$ supplied from urea $+10 \mathrm{~kg} \mathrm{~N}$ supplemented by cowdung; $\mathrm{T}_{3}: 70 \mathrm{~kg} \mathrm{~N}$ supplied from urea+20 kg N supplemented by cowdung; $\mathrm{T}_{4}: 60 \mathrm{~kg} \mathrm{~N}$ supplied from urea+30 kg $\mathrm{N}$ supplemented by cowdung; $\mathrm{T}_{5}: 50 \mathrm{~kg} \mathrm{~N}$ supplied from urea+40 kg N supplemented by cowdung; $\mathrm{T}_{6}: 40 \mathrm{~kg} \mathrm{~N}$ supplied from urea+50 kg N supplemented by cowdung; $T_{7}: 30 \mathrm{~kg} \mathrm{~N}$ supplied from urea+60 kg N supplemented by cowdung; $\mathrm{T}_{8}: 90 \mathrm{~kg} \mathrm{~N}$ supplied from cowdung; $T_{9}$ : Control

The experimental field was first opened with the help of a power tiller and prepared by three successive ploughing and cross-ploughing. Manures and fertilizers were applied to the experimental plot as per the fertilizer recommendation guide, 2005. The total amount of cowdung, TSP, MoP, zinc and sulphur was applied as basal dose at the time of final land preparation. Urea was applied in two installments at 15 and 30 days after seed sowing. Seeds of BARI bush bean-1 were sown in rows with maintaining the spacing of $30 \times 15 \mathrm{~cm}^{2}$. Light over-head irrigation was provided with a watering can to the plots immediately after germination of seedlings. Irrigation also provided at 10 and 25 days after seed sowing. Dead, injured and week seedlings were replaced by healthy one from the stock kept on the border line of the experimental plot.

Weeding was done two times at 10 and 25 days after seed sowing followed by irrigation in the plots considering the optimum time for removal weed. The harvesting was done when the pod attend full maturity. Ten plants were randomly selected from each unit plot for data collection. Data were collected in respect of the plant growth and yield characteristics of bush bean. Data on plant height $(\mathrm{cm})$, number of branches, leaves, flowers and pods per plant, length of green pod $(\mathrm{cm})$, and weight of fresh pod $(\mathrm{kg})$ were collected at final harvesting.

Soil samples were analyzed for determining organic matter, $\mathrm{pH}$, total $\mathrm{N}$, available $\mathrm{P}$, available $\mathrm{S}$ and exchangeable $\mathrm{K}$ contents. Soil $\mathrm{pH}$ was measured with the help of a glass electrode $\mathrm{pH}$ meter, the soil water ratio being maintained at 1: 2.5 (Jackson, 1962). Organic carbon in soil sample was determined by Walkley and Black (1935) wet oxidation method. Total nitrogen content in soil was determined by Kjeldahl method (Black, 1965). Available Phosphorus was extracted from soil shaking with $0.5 \mathrm{M} \mathrm{NaHCO}_{3}$ solution of $\mathrm{pH} 8.5$ (Olsen et al., 1954). Available Sulphur in soil was determined by extracting the soil sample with $0.15 \% \mathrm{CaCl}$ solution (Page et al., 1982). The data obtained for different characters were statistically analyzed to find out the significance of the difference among the treatments. The mean values of all the characters were evaluated and analysis of variance was done by the ' $F$ ' (variance ratio) test. The mean differences were evaluated by 
Least Significant Difference (LSD) at 0.05 level of probability (Gomez and Gomez, 1984).

\section{Results and Discussion}

The experiment was conducted to find out the suitability of BARI bush bean-1 with the application of nitrogenous fertilizer from different sources viz. inorganic urea and organic cowdung. The results have been discussed and possible interpretations given under the following headings:

\subsection{Effect of nitrogenous fertilizer from different organic and} inorganic sources on the growth parameters of bush bean

\subsubsection{Plant height}

Plant height of bush bean showed significant variation due to the application of mineral nitrogen along with cowdung (Table 1). The highest plant height $(43.67 \mathrm{~cm})$ was recorded from $T_{5}$ ( $50 \mathrm{~kg} \mathrm{~N}$ from urea $+40 \mathrm{~kg} \mathrm{~N}$ supplemented by cowdung) which was statistically identical with the treatment $T_{1}, T_{2}, T_{3}, T_{4}, T_{6}, T_{7}$ and $T_{8}$ respectively, while the shortest plant $(33.67 \mathrm{~cm})$ was found from $T_{9}$ (control) treatment with no fertilizer. The data

Table 1: Effect of nitrogenous fertilizer from different organic and inorganic sources on growth parameters of bush bean

\begin{tabular}{lcccccc}
\hline $\mathrm{T}$ & $\mathrm{PH}$ & $\mathrm{Np}$ & NSP & NBP & NFP & NPP \\
\hline $\mathrm{T}_{1}$ & $40.33^{\mathrm{a}}$ & $20.54^{\mathrm{f}}$ & $5.07^{\mathrm{f}}$ & $6.56^{\mathrm{ab}}$ & $25.67^{\mathrm{ab}}$ & $20.0^{\mathrm{b}}$ \\
$\mathrm{T}_{2}$ & $36.67^{\mathrm{ab}}$ & $21.44^{\mathrm{f}}$ & $5.13^{\mathrm{f}}$ & $7.33^{\mathrm{a}}$ & $19.67^{\mathrm{b}}$ & $18.7^{\mathrm{b}}$ \\
$\mathrm{T}_{3}$ & $42.00^{\mathrm{a}}$ & $23.07^{\mathrm{e}}$ & $5.15^{\mathrm{f}}$ & $7.00^{\mathrm{a}}$ & $20.00^{\mathrm{b}}$ & $19.0^{\mathrm{b}}$ \\
$\mathrm{T}_{4}$ & $38.00^{\mathrm{ab}}$ & $26.55^{\mathrm{ab}}$ & $5.50^{\text {def }}$ & $7.00^{\mathrm{a}}$ & $17.67^{\mathrm{bc}}$ & $16.3^{\mathrm{bc}}$ \\
$\mathrm{T}_{5}$ & $43.67^{\mathrm{a}}$ & $27.33^{\mathrm{a}}$ & $6.50^{\mathrm{a}}$ & $7.66^{\mathrm{a}}$ & $27.67^{\mathrm{a}}$ & $25.0^{\mathrm{a}}$ \\
$\mathrm{T}_{6}$ & $41.67^{\mathrm{a}}$ & $24.55^{\text {de }}$ & $6.00^{\mathrm{bcd}}$ & $6.33^{\mathrm{ab}}$ & $27.00^{\mathrm{a}}$ & $24.3^{\mathrm{a}}$ \\
$\mathrm{T}_{7}$ & $40.33^{\mathrm{a}}$ & $23.85^{\text {de }}$ & $5.70^{\text {def }}$ & $6.33^{\mathrm{ab}}$ & $25.67^{\mathrm{ab}}$ & $23.0^{\mathrm{ab}}$ \\
$\mathrm{T}_{8}$ & $41.33^{\mathrm{a}}$ & $23.90^{\text {de }}$ & $5.56^{\text {def }}$ & $7.60^{\mathrm{a}}$ & $13.33^{\mathrm{c}}$ & $12.0^{\mathrm{c}}$ \\
$\mathrm{T}_{9}$ & $33.67^{\mathrm{c}}$ & $18.59^{\mathrm{g}}$ & $4.01^{\mathrm{g}}$ & $5.33^{\mathrm{c}}$ & $12.33^{\mathrm{c}}$ & $11.3^{\mathrm{c}}$ \\
LSD & 8.620 & 1.37 & 0.26 & 2.277 & 18.14 & 79.83 \\
value & & & & & & \\
\hline
\end{tabular}

T: Treatments; PH: Plant height (cm); NP: No. of plants $\mathrm{m}^{-2}$; NSP: No. of seeds pod ${ }^{-1}$; NBP: No. of branches Plant ${ }^{-1}$; NFP: No. of flowers Plant ${ }^{-1}$; NPP: No. of pods plant ${ }^{-1}$; In a column means having similar letter(s) are statistically similar and those having dissimilar letter(s) differ significantly as per 0.05 level of probability

revealed that all the treatments produced significantly taller plants compared to the control. Increase in plant height due to the application of different level of $\mathrm{N}$ from inorganic and organic sources might be associated with stimulating effect of nitrogen on various physiological process including cell division and cell elongation of the plant. Mahase et al. (2007), Vishwakarma et al. (2002), Farkadeet and Pawar (2002) also reported similar results from their earlier experiment using nitrogen.

\subsubsection{No. of plants $m^{-2}$}

The number of plants per square meter of the experimental crop varied significantly influenced by the application of different nitrogen levels along with organic manure cowdung (Table 1). The highest number of plant per square meter (27.33) was recorded from the $T_{5}$ treatment that received 50 $\mathrm{kg} \mathrm{N}$ supplied from urea $+40 \mathrm{~kg} \mathrm{~N}$ supplemented by cowdung, which was statistically similar with $\mathrm{T}_{4}$ treatment. The lowest number of plant per square meter (18.59) was obtained in the control treatment. Vishwakarma et al. (2002) found the similar results with using nitrogen fertilizer in bush bean.

\subsubsection{No. of seeds pod ${ }^{-1}$}

There were significant differences among the different levels of $\mathrm{N}$ along with organic manure cowdung on seeds per green pod (Table 1). The number of seed per green pods ranged from 5.07 to 6.50 . The maximum number of seeds per green pod (6.50) was found at $T_{5}$ treatment that received $50 \mathrm{~kg} \mathrm{~N}$ supplied from urea+40 $\mathrm{kg} \mathrm{N}$ supplemented by cowdung which was followed $\mathrm{T}_{6}$ treatment with $40 \mathrm{~kg} \mathrm{~N}$ supplied from urea + $50 \mathrm{~kg} \mathrm{~N}$ supplemented by cowdung and the lowest number of seed per green pod (5.07) was obtained in the control treatment. The application of nitrogen produced significantly the higher number of seeds per pod of bush bean, as reported by Mahase et al. (2007); Vishwakarma et al. (2002); Farkadeet and Pawar (2002).

\subsubsection{No. of branches plant ${ }^{1}$}

Significant variations were recorded for number of branches per plant of bush bean due to the application of mineral and organic $\mathrm{N}$ (Table 1). The maximum number of branches per plant (7.66) was obtained from $\mathrm{T}_{5}(50 \mathrm{~kg} \mathrm{~N}$ from urea $+40 \mathrm{~kg} \mathrm{~N}$ supplemented by cowdung) which was statistically identical with the treatments $T_{1}, T_{2}, T_{3}, T_{4}, T_{6}, T_{7}$ and $T_{8}$ respectively. All the treatments produced significantly highest number of branches per plant compared to the control. Vishwakarma (2002) found that number of branches per plant was significantly influenced by higher dose of nitrogen in case of bean.

\subsubsection{No. of flowers plant ${ }^{1}$}

Statistically significant differences were found due to the application of mineral $\mathrm{N}$ and organic $\mathrm{N}$ in respect of number of flowers per plant of bush bean (Table 1). The maximum number of flowers plant ${ }^{-1}$ (27.67) was observed from $T_{5}(50$ $\mathrm{kg} \mathrm{N}$ from urea $+40 \mathrm{~kg} \mathrm{~N}$ supplemented by cowdung) which was statistically identical with $\mathrm{T}_{1}, \mathrm{~T}_{6}$ and $\mathrm{T}_{7}$ treatments. In contrast, the minimum number of flowers plant ${ }^{-1}$ (12.33) was observed from control treatment, which was statistically identical with $\mathrm{T}_{8}$ ( $90 \mathrm{~kg} \mathrm{~N}$ supplied from cowdung). Optimum level of nitrogen ensured reproductive growth of plant through optimum vegetative growth. Chaib et al. (1984) reported that Nitrogen fertilizer at optimum doses promoted growth and development as well as flower initiation of bush bean. 


\subsubsection{No. of pods plant ${ }^{-1}$}

Nitrogen had a significant effect on number of pods per plant. Number of pods per plant of bush bean showed significant variation due to the application of mineral and organic source of $\mathrm{N}$ (Table 1). The maximum number of pods per plant (25.0) was obtained from $\mathrm{T}_{5}$ (50 kg N from urea+40 kg N supplemented by cowdung) treatment which was statistically identical with the treatment $T_{6}$ and $T_{7}$ treatments. And the minimum number of pods per plant (11.3) was obtained from treatment $\mathrm{T}_{9}$ with no chemical or organic $\mathrm{N}$ fertilizer. Judicious applications of nitrogen fertilizer minimize leaching or washed out and maximized crop production. Rahman (2001) found that pods plant ${ }^{-1}$ were significantly influenced by higher dose of nitrogen.

3.2. Effect of nitrogenous fertilizer from different organic and inorganic sources on the yield and yield parameters of bush bean

\subsubsection{Pod length}

Significant variation was observed in pod length of bush bean due to application of mineral $\mathrm{N}$ along with cowdung (Table 2). The highest length of pods $(12.89 \mathrm{~cm})$ was recorded from $\mathrm{T}_{5}$ (50 kg N from urea+40 kg N supplemented by cowdung) treatment, which was statistically similar with the treatment $T_{1}, T_{2}, T_{3}, T_{4}, T_{6}, T_{7}$ and $T_{8}$ respectively. While the lowest pod length $(10.11 \mathrm{~cm})$ was obtained from $T_{9}$ (control) treatment. An optimum amount of nitrogen for the whole growth period is necessary to produce maximum yield of good quality bush bean. Farkadeet et al. (2002) cited that nitrogen had a positive effect on pod length of bush bean.

\subsubsection{Weight of 1000 pods}

Mineral $\mathrm{N}$ with the application of cowdung varied significantly in terms of weight of total pods (Table 2). The highest weight of 1000 pods $(4.71 \mathrm{~kg}$ ) at each harvesting was recorded from $\mathrm{T}_{5}$ (50 kg N from urea+40 kg N supplemented by cowdung),

\begin{tabular}{lccc}
\hline \multicolumn{3}{c}{ Table 2: Effect of nitrogenous fertilizer from different organic } \\
\multicolumn{4}{c}{ and inorganic sources on yield parameters of bush bean } \\
\hline $\mathrm{T}$ & $\begin{array}{c}\text { Length of } \\
\text { pod }(\mathrm{cm})\end{array}$ & $\begin{array}{c}\text { Weight of } 1000 \\
\text { pods }(\mathrm{kg})\end{array}$ & $\begin{array}{c}\text { Pod yield } \\
\left.(\mathrm{t} \mathrm{ha})^{-1}\right)\end{array}$ \\
\hline $\mathrm{T}_{1}$ & $12.11^{\mathrm{a}}$ & $4.11^{\mathrm{a}}$ & $10.08^{\mathrm{b}}$ \\
$\mathrm{T}_{2}$ & $12.61^{\mathrm{a}}$ & $4.36^{\mathrm{a}}$ & $9.64^{\mathrm{bc}}$ \\
$\mathrm{T}_{3}$ & $12.221^{\mathrm{a}}$ & $4.66^{\mathrm{a}}$ & $10.10^{\mathrm{b}}$ \\
$\mathrm{T}_{4}$ & $12.11^{\mathrm{a}}$ & $4.28^{\mathrm{a}}$ & $9.68 \mathrm{~b}^{\mathrm{c}}$ \\
$\mathrm{T}_{5}$ & $12.89^{\mathrm{a}}$ & $4.71^{\mathrm{a}}$ & $13.44^{\mathrm{a}}$ \\
$\mathrm{T}_{6}$ & $12.112^{\mathrm{a}}$ & $4.20^{\mathrm{a}}$ & $11.57^{\mathrm{ab}}$ \\
$\mathrm{T}_{7}$ & $12.22^{\mathrm{a}}$ & $4.70^{\mathrm{a}}$ & $11.78^{\mathrm{ab}}$ \\
$\mathrm{T}_{8}$ & $12.612^{\mathrm{a}}$ & $4.53^{\mathrm{a}}$ & $10.72^{\mathrm{b}}$ \\
$\mathrm{T}_{9}$ & $10.11^{\mathrm{b}}$ & $3.99^{\mathrm{b}}$ & $8.48^{\mathrm{c}}$ \\
$\mathrm{LSD}^{\mathrm{b}}$ & 1.0689 & 1.3160 & 5.0231 \\
\hline
\end{tabular}

which was closely related with the treatment, $T_{2}, T_{3}, T_{4}, T_{6}, T_{7}$ and $T_{8^{\prime}}$, respectively. While the lowest weight (3.99 kg) was obtained from control treatment. Rahman (2001) found that individual pod weights were significantly influenced by higher dose of nitrogen.

\subsubsection{Pod yield $\left(t h a^{-1}\right)$}

Application of $\mathrm{N}$ had a significant influence on pod yield of bush bean. Green pod yield ( $\mathrm{t} \mathrm{ha}^{-1}$ ) showed statistically significant differences due to the application of mineral $\mathrm{N}$ along with cowdung (Table 2). Highest pod yield of bush bean $\left(13.44 \mathrm{t} \mathrm{ha}^{-1}\right)$ was recorded from $\mathrm{T}_{5}(50 \mathrm{~kg} \mathrm{~N}$ from urea $+40 \mathrm{~kg} \mathrm{~N}$ supplemented by cowdung) treatment, which was statistically similar with $\mathrm{T}_{6}$ and $\mathrm{T}_{7}$ treatments respectively The minimum green pod yield of bush bean was found $\left(8.48 \mathrm{t} \mathrm{ha}^{-1}\right)$ from $\mathrm{T}_{9}$ treatment that received no $\mathrm{N}$ fertilizer from organic and inorganic sources, which was statistically different from all other treatments. Mahase et al. (2007) found that pod yield of bush bean was significantly influenced by higher dose of nitrogen.

\subsection{Effect of nitrogenous fertilizer from different organic and inorganic sources on post harvest soil}

\subsubsection{Soil $p H$}

There were no significant variations recorded for $\mathrm{pH}$ due to the application of mineral nitrogen and organic cowdung (Table 3). The highest $\mathrm{pH}$ (6.11) was found in the treatment $\mathrm{T}_{4}$, and the lowest $\mathrm{pH}$ (5.75) was found in the treatment $\mathrm{T}_{9}$.

\subsubsection{Organic carbon content}

Organic carbon content in soil sample showed statistically significant differences due to mineral nitrogen with cowdung (Table 3). Organic carbon content of the soil shows statistical

Table 3: Effect of nitrogenous fertilizer from different organic and inorganic sources on the post-harvest soil nutrient status

\begin{tabular}{|c|c|c|c|c|c|c|}
\hline $\mathrm{T}$ & $\mathrm{pH}$ & OC & $\mathrm{TN}$ & AP & AS & EP \\
\hline $\mathrm{T}_{1}$ & 5.80 & $0.52^{\mathrm{ab}}$ & $0.070^{a}$ & $15.0^{\mathrm{abc}}$ & $13.35^{b}$ & $0.144^{b}$ \\
\hline $\mathrm{T}_{2}$ & 6.00 & $0.44^{b}$ & $0.064^{a}$ & $19.0^{\mathrm{ab}}$ & $13.41^{b}$ & $0.143^{b}$ \\
\hline $\mathrm{T}_{3}$ & 6.10 & $0.65^{a b}$ & $0.068^{a}$ & $14.8^{b c}$ & $14.7^{a}$ & $0.161^{a b}$ \\
\hline $\mathrm{T}_{4}$ & 6.11 & $0.66^{a}$ & $0.065^{a}$ & $14.1^{c}$ & $13.86^{\mathrm{ab}}$ & $0.140^{b}$ \\
\hline $\mathrm{T}_{5}$ & 5.80 & $0.63^{a b}$ & $0.050^{b}$ & $22.0^{a}$ & $14.9^{a}$ & $0.164^{a b}$ \\
\hline $\mathrm{T}_{6}$ & 6.10 & $0.68^{a}$ & $0.062^{a}$ & $14.0^{c}$ & $14.95^{\mathrm{a}}$ & $0.173^{a}$ \\
\hline $\mathrm{T}_{7}$ & 6.00 & $0.69^{a}$ & $0.055^{a b}$ & $15.2^{\mathrm{abc}}$ & $13.08^{\mathrm{ab}}$ & $0.170^{a}$ \\
\hline $\mathrm{T}_{8}$ & 5.90 & $0.70^{a}$ & $0.063^{a}$ & $18.0^{\mathrm{ab}}$ & $15.0^{\mathrm{a}}$ & $0.182^{a}$ \\
\hline $\mathrm{T}_{9}$ & 5.75 & $0.21^{a}$ & $0.031^{c}$ & $15.05^{a b c}$ & $12.01^{\mathrm{c}}$ & $0.122^{c}$ \\
\hline $\begin{array}{l}\text { LSD } \\
\text { value }\end{array}$ & NS & 3.017 & 3.002 & 0.05474 & 3.0164 & 1.9754 \\
\hline $\begin{array}{l}\text { phos } \\
\text { Excha }\end{array}$ & $\begin{array}{l}\text { nic c } \\
\text { orus } \\
\text { eable }\end{array}$ & pm) & $\begin{array}{l}\text { TN: Tc } \\
\text { S: Av } \\
\text { n (me }\end{array}$ & $\begin{array}{l}\text { nitro } \\
\text { able } \\
100 \mathrm{~g}^{-}\end{array}$ & $\begin{array}{l}\text { (\%); A } \\
\text { hur } \\
\text { I) }\end{array}$ & $\begin{array}{l}\text { Available } \\
\text { m); EP: }\end{array}$ \\
\hline
\end{tabular}


variations due to effect of the different doses of organic and inorganic based nitrogen application. Maximum content of organic carbon $(0.70 \%)$ was found in the treatment $\mathrm{T}_{8}$, which was statistically similar with the treatments $T_{1}, T_{3}, T_{4}, T_{5}, T_{6}$ and $T_{7}$. On the other hand, minimum organic carbon $(0.21 \%)$ content was found in the treatment $T_{9}$.

\subsubsection{Total nitrogen content}

Nitrogen content in soil sample (\%) showed statistically significant differences due to mineral $\mathrm{N}$ with cowdung (Table 3 ). Nitrogen content of the studied soil shows statistical variations due to effect of the different doses of organic and inorganic based nitrogen application. However, maximum content of nitrogen 0.07 (\%) was found in the treatment $T_{1}$ which was statistically similar with the treatments $T_{2}, T_{3}, T_{4}, T_{6}$, $\mathrm{T}_{7}$ and $\mathrm{T}_{8}$, respectively. On the contrary, the minimum nitrogen $(0.031 \%)$ content was found in $\mathrm{T}_{9}$ treatment.

\subsubsection{Available phosphorus content}

Phosphorus content in soil sample showed statistically significant differences due to mineral $\mathrm{N}$ with cowdung (Table 3). Phosphorus content of the studied soil shows statistical variations due to the application of different doses of organic and inorganic based nitrogen. However, maximum content of Phosphorus 22.0 (ppm) was found in the treatment $\mathrm{T}_{5}$, which was statistically similar with the treatments $T_{1}, T_{2}, T_{7}, T_{8}$, and $\mathrm{T}_{9}$, respectively. The minimum phosphorus (14.0 ppm) content was found in the treatment $\mathrm{T}_{3}$ and $\mathrm{T}_{4}$, which was statistically different from other treatments.

\subsubsection{Available sulphur content}

Sulfur content in soil sample (\%) showed statistically significant differences due to mineral nitrogen and cowdung (Table 3). Maximum content of sulphur content (15.0 ppm) was found in the treatment $T_{8}$, which was statistically similar with the treatments $T_{3}, T_{4}, T_{5}, T_{6}$ and $T_{7}$, respectively. On the other hand, minimum sulphur content (12.01 ppm) content was found in the treatment $T_{9}$, which was statistically different from other treatments.

\subsubsection{Exchangeable potassium content (meq $100 \mathrm{~g}^{-1}$ soil)}

Potassium content in soil sample showed statistically significant differences due to mineral $\mathrm{N}$ with cowdung (Table 3). Maximum content of potassium (0.182 meq $100 \mathrm{~g}^{-1}$ soil) was found in the treatment $\mathrm{T}_{8}$, which was statistically similar with the treatments $T_{3}, T_{5}, T_{6}$ and $T_{7}$. On the Other hand, minimum potassium content $\left(0.122\right.$ meq $100 \mathrm{~g}^{-1}$ soil) was found in the treatment $T_{9}$.

\section{Conclusion}

Application of nitrogenous fertilizer found effective on respect of growth, yield and soil nutrient status of Bush Bean. The application of different level of $\mathrm{N}$ from inorganic and organic sources had a stimulating effect on growth, development and various physiological process including cell division and cell elongation of the bush bean plant. From the study it was concluded that application of $50 \mathrm{~kg}$ nitrogen from urea and $40 \mathrm{~kg}$ from cow dung was best treatment combination for optimum growth and yield of bush bean.

\section{References}

AICPIP, 1987. Consolidated Report on Rabi Pulses. Directorate of Pulse Research, Kanpur, 62-67.

Ali, M., Kushwaha, B.I., 1987. Cultivation of Rabi rajmash in plants. Indian Farming 37(2), 20-23.

Anonymous, 1989. Annual Report 1987-88. Bangladesh Agricultural Research Institute. Joydebpur, Gazipur, 133.

BARI, 2006. Krishi Projukti Hathboi. Bangladesh Agricultural Research Institute. Joydebpur, Gazipur.

Bhatnagar, V.K., Choudhary, T.N., Sharma, B.R., 1983. Effect of tillage and residue management on properties of two coarse-textured soils and on yield of irrigated wheat and groundnut. Soil and Tillage Research 3, 27-37.

Bill, U., 2001. Manure and soil organic matter. Pennsylvania Stat Field Crop News 01, 11.

Black, C.A., 1965. Methods of Soil Analysis. Part 2, American Soci. Agro. Inc., Madison, Wisconsin, USA, 1149-1178.

Chaib, S.L., Bulisami, E.A., Castro, L.H.S.M., 1984. Growth and yield of bush beans as affected by depth of phosphate fertilizer application. Pesquisa Agropecudria Brasileira 19(7), 817-822.

Duke, J.A., 1983. Hand Book of Legumes of World Economic Importance, (2 ${ }^{\text {nd }}$ Edn.), Plenum Press, New York, 341.

FAO, 2000. Production Year Book. Food and Agricultural Organization of the United Nations. Rome, Italy 54, 108.

Farkadeet, B.K., Pawar, W.S., 2002. Growth performance and yield of french bean varieties as influenced by different fertilizer levels. Indian Journal of Agricultural Sciences 12(1), 142-144.

Gomez, K.A., Gomez, A.A., 1984. Statistical Procedure for Agricultural Research, (2 ${ }^{\text {nd }}$ Edn. $)$, Jhon Willey and Sons, New York, 28-192.

IFIA, 1992. Sustainable agricultural system for the $21^{\text {st }}$ centurythe role of mineral fertilizer. International Fertilizer Industry Association. Pans, France, 16.

Jackson, M.L., 1962. Soil Chemical Analysis. Prentice Hall Inc. New Jersey New York, USA.

Mahase, N.N., Pattiwar, V.V., Deshpande, R.M., Raut, P.B., Adagale, M.W., Borkar, L.S., 2007. Effect of nitrogen and irrigation levels on yield and water use of French bean (Phaseolus vulgaris). Journal of Soils and Crops 17(2), 379-382.

Olsen, S.R., Cole, C.V., Watanabe, F.S., Dean, L.A., 1954. Estimation of available phosphorus in soils by extraction with sodium bicarbonate, U.S. Department of Agricultural Circular, 929.

Page, A.L., Miller, R.H., Keency, D.R., 1982. Methods of soil analysis. Part II ( $2^{\text {nd }}$ ed.). Amer. Soc. Agron. Inc. Madison, Winsconsin, USA, 403-430.

Purseglove, J.W., 1987. Tropical Crops: Dicotyledons. Longman, 
New York, 52.

Rashid, M.M., 1993. Sabji Biggan (in Bengali), (1 ${ }^{\text {st }}$ Edn.), Bangla Academy, Bangladesh, 387-390.

Saha, P.K., Ishaque, M., Saleque, M.A., Miah, M.A.M., Panaullah, G.M., Bhuiyan, N.I., 2007. Long-term integrated nutrient management for rice-based cropping pattern: Effect on growth, yield, nutrient uptake, nutrient balance sheet and soil fertility. Communications in Soil Science and Plant Analysis 38, 579-610.

Salukhe, D.K., Desai, B.B., Bhat, N.R., 1987. Leguminous Vegetables (Peas and Beans). In: Vegetabes and Flower Seed Production, Agricole Publishing Academy, New Delhi, 265-302.

Sangakkara, U.R., 1993. Effect of EM on Nitrogen and Potassium levels in the Rhizosphere of Bush Bean. Third International Conference on Kyusei Nature Farming 1993. Sanat Barbara, California, USA.
Shanmugavelu, K.G., 1989. Production technology of vegetable crops. Oxford and IBH Publishing Co. Pvt. Ltd., New Delhi, 446-461.

Swiader, J.M., Ware, G.W., McCollum, J.P., 1992. Producing Vegetable Crops (4 ${ }^{\text {th }}$ Edn.), Interstate Publishers, Inc. Danville, Illions, USA, 223-249.

Tindall, H.D., 1988. Vegetables in the tropics. McMillah education Ltd., 527.

Vishwakarma, B., Singh, C.S., Rajesh, S., Singh, R., 2002. Response of french bean (Phaseolus vulgaris $L$ ) varieties to nitrogen application. Research on Crops 3(3), 529-532.

Walkley, A., Black, D.R., 1935. An examination of the digestion method for determining soil organic matter and proposed modification of the chronic acid titration method. Soil Science 37, 29-38. 